\title{
PEMBELAJARAN DENGAN MODEL DISCOVERI LEARNING BERBANTUKAN GEOGEBRA PADA MATERI BANGUN RUANG DI KELAS V SD YPK DIASPORA PKS ARSO 7
}

\author{
Dewi Kristika Findia Ning Tyas ${ }^{1)}$, Matius Pai'pinan ${ }^{2)}$ \\ 1,2 Program Studi Pendidikan Matematika, FKIP, Universitas Cenderawasih \\ dewikristikafindy@yahoo.co.id ${ }^{1)}$, mathpinan@gmail.com ${ }^{2)}$
}

Abstrak. Sesuai dengan tujuan dari penelitian ini yaitu mendiskripsikan pembelajaran dengan model discoveri learning berbantukan geogebra pada materi bangun ruang di kelas V SD YPK diaspora PKS Arso 7 maka jenis penelitian yang dipilih adalah penelitian deskriptif dengan pendekatan kualitatif. Subjek dalam penelitian ini adalah siswa kelas V SD YPK Diaspora PKS Arso 7 yang berjumlah 16 siswa. Dalam pembelajaran discoveri learning terdapat enam tahapan yaitu: stimulation, Problem Statement, data collection (pengumpulan data), data processing (pengelolaan data), verification (pembuktian) dan generalization (penarikan kesimpulan). Pada tahap pertama, siswa diberikan stimulasi berupa permasalahan yang ditampilkan dengan menggunakan media geogebra, untuk selanjutnya pada tahap kedua guru memberikan kesempatan kepada siswa untuk mengidentifikasi sebanyak mungkin kejadian-kejadian dari masalah yang diberikan. Tahap ketiga siswa membuktikan terkait pernyataan yang ada sehingga siswa mempunyai kesempatan mengumpulkan informasi yang sesuai. Tahap keempat, data processing (pengelolaan data) merupakan kegiatan mengolah data dan informasi yang diperoleh siswa sebelumnya. Kelima, verification (pembuktian) yaitu kegiatan membuktikan jawaban sementara siswa yang sudah diketahui dan dihubungkan dengan hasil data yang sudah ada. Keenam, generalization (penarikan kesimpulan) yaitu proses dimana membuat kesimpulan yang akan dijadikan prinsip umum semua masalah yang sama. Berdasarkan hasil observasi sikap siswa berada kategori sangat baik, demikian halnya dengan hasil observasi proses keterlaksanaan model pembelajaran. Hasil belajar siswa menunjukkan lebih dari separuh siswa memenuhi KKM. Selama pembelajaran siswa terlihat antusias.

Kata kunci: Discoveri Learning, Geogebra, Volum Kubus dan Balok

\section{PENDAHULUAN}

Saat ini kita hidup di era revolusi industri keempat atau dikenal dengan revolusi industri 4.0. Revolusi industri 4.0 adalah nama tren otomasi dan pertukaran data terkini dalam teknologi pabrik. Revolusi industri 4.0 berdampak pada semua bidang, termasuk pendidikan. Menjadi tantangan bagi dunia pendidikan agar dapat mengikuti perkembangan zaman.

Pendidikan yang diharapkan di masa Revolusi industri 4.0 yaitu adanya perubahan cara belajar, pola berfikir, serta cara bertindak baik oleh siswa maupun guru. Hal ini senada dengan salah satu Misi Program Studi Pendidikan Matematika Fakultas Keguruan dan Ilmu Pendidikan Universitas Cenderawasih yaitu mengembangkan pembelajaran matematika aktif, inovatif, kreatif, efektif dan menyenangkan berbasis IPTEKS. Berdasarkan misi tersebut diharapkan Program Studi Pendidikan Matematika menghasilkan guruguru matematika yang handal dan profesional.

Untuk menciptakan pembelajaran matematika aktif, inovatif, kreatif, efektif dan menyenangkan berbasis IPTEKS hendaknya guru-guru matematika dapat mengembangkan model pembelajaran inovatif dikolaborasikan dengan media/aplikasi. Ada beberapa jenis model pembelajaran inovatif, salah satunya model pembelajaran discovery learning. Discovery learning atau belajar penemuan adalah belajar yang dihasilkan dari memanipulasi objek, membuat struktur 
mentransformasikan informasi sedemikian sehingga ditemukanlah informasi baru. Siswa diharuskan membuat perkiraan, merumuskan suatu kebenaran, dan menemukan kebenaran, menggunakan proses induktif atau deduktif serta melakukan observasi dan mebuat perluasan dari hasil yang ditemukan. Dengan pembelajaran ini siswa akan aktif, karena pembelajaran tidak berpusat pada guru.

Model pembelajaran discovery learning dapat dikolaborasikan dengan media/aplikasi, salah satunya geogebra. Geogebra adalah program komputer untuk membelajarkan matematika khususnya geometri dan aljabar. Dengan geogebra guru dan siswa dapat dimudahkan dalam memahami materi geogebra dan aljabar.

Penulis melakukan observasi awal di salah satu Sekolah Dasar Swasta di Kabupaten Keerom. Penulis mencari informasi awal apakah guru telah menggunakan model pembelajaran inovatif dan media/aplikasi dalam pembelajaran matematika. Penulis memilih Sekolah Dasar karena Sekolah Dasar merupakan tingkatan satuan pendidikan dimana siswa untuk pertama kali menerima konsep. Sangat penting bagi siswa untuk memahami konsep, terlebih jika materi tersebut materi dasar yang akan diperoleh kembali siswa di satuan pendidikan selanjutnya yaitu di SMP dan SMA bahkan Perguruan Tinggi jika nantinya siswa tersebut mengambil kosentrasi matematika pada saat kuliah. Penulis memilih Sekolah Dasar Swasta yaitu Sekolah Dasar YPK Diaspora Arso 7 yang didominasi oleh anak asli papua karena penulis berkeinginan agar anak-anak tersebut mampu bersaing.

Berdasarkan hasil observasi di sekolah tersebut diperoleh informasi: 1) guru-guru belum menerapkan model pembelajaran inovatif dan media/aplikasi, termasuk model pembelajaran discoveri learning dan geogebra; 2) guru-guru kesulitan dalam menjelaskan materi bangun ruang; 3) Siswa kesulitan dalam mengkonstruk bangun ruang; 4) tidak adanya alat peraga 5) dalam pembelajaran siswa pasif, siswa hanya mendengar. Materi bangun ruang selain diajarkan di Sekolah Dasar, diajarkan juga di Sekolah Menengah Pertama, dan Sekolah Menengah Atas. Materi bangun ruang selalu diujikan dalam ujian Nasioal di semua jenjang pendidikan.

\section{METODE PENELITIAN}

Sesuai dengan tujuan dari penelitian ini yaitu mendiskripsikan pembelajaran dengan model discoveri learning berbantukan geogebra pada materi bangun ruang di kelas V SD YPK diaspora PKS Arso 7 maka jenis penelitian yang dipilih adalah penelitian deskriptif dengan pendekatan kualitatif. Subjek dalam penelitian ini adalah siswa kelas V SD YPK Diaspora PKS Arso 7 yang berjumlah 16 siswa. Instrumen yang digunakan dalam penelitian ini yaitu (1) Lembar observasi guru, untuk melihat apakah pembelajaran sudah sesuai dengan langkah-langkah model pembelajaran Discovery Learning, (2) Lembar observasi siswa, untuk melihat perkembangan sikap siswa, (3) lembar tes, untuk melihat seberapa jauh pemahaman siswa pada materi yang diajarkan. Teknik pengambilan data yaitu observasi dan tes. Observasi guru dan siswa dilakukan selama proses pembelajaran, sedangkan tes dilakukan setelah pembelajaran. Observer adalah guru kelas V. Proses analisis data dilakukan sebelum, saat, dan sesudah penelitian.

\section{HASIL DAN PEMBAHASAN \\ Paparan Hasil Penelitian}

Proses Penerapan Model Pembelajaran Discovery Learning Berbantukan Geogebra

Tanggal 7 Agustus 2019 peneliti melaksanakan penelitian yaitu dengan menerapkan model pembelajaran discovery learning berbantukan geogebra dengan alokasi waktu 3 x 35 menit. Dalam pelaksanaan proses pembelajaran guru mengawali dengan kegiatan pendahuluan dengan mengucapkan salam dan mengajak siswa untuk berdoa terlebih dahulu, doa dipimpin oleh salah satu siswa. Selanjutnya guru mengecek kehadiran siswa, semua siswa hadir sehingga siswa yang mengikuti pembelajaran berjumlah 16 siswa dan menyiapkan siswa untuk mulai belajar dengan 
cara menurunkan tas mereka dari meja sehingga hanya tersisa alat tulis yang di atas meja. Pada langkah selanjutnya guru menyampaikan materi yang akan dipelajari hari ini dengan menuliskan pokok bahasannya di papan tulis kemudian dilanjutkan dengan menyampaikan tujuan pembelajaran. Kemudian apersepsi guru mengingatkan lagi perkalian dan pangkat tiga.

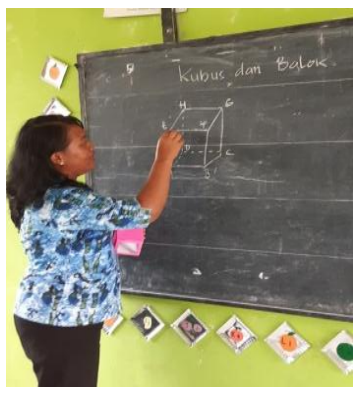

Gambar 4.3 Guru menuliskan pokok bahasannya di papan tulis kemudian dilanjutkan dengan menyampaikan tujuan pembelajaran

Pada langkah terakhir dalam kegiatan pendahuluan guru memberikan contoh bangun ruang yang akan dipelajari yaitu kubus dan balok dan menyebutkan contoh-contoh bangun/benda di sekitar yang berbentuk kubus dan balok, misalnya tempat bak mandi, tempat sabun mandi, tempat pasta gigi dll. Selanjutnya memotivasi siswa dengan menyebutkan penerapan rumus volum kubus dan balok dalam kehidupan sehari-hari, misalnya siswa dapat menghitung volum air dalm bak yang berbentuk kubus dan balok. Guru meminta agar siswa serius dalam kegiatan pembelajaran karena diakhir pembelajaran akan diadakan tes individu.

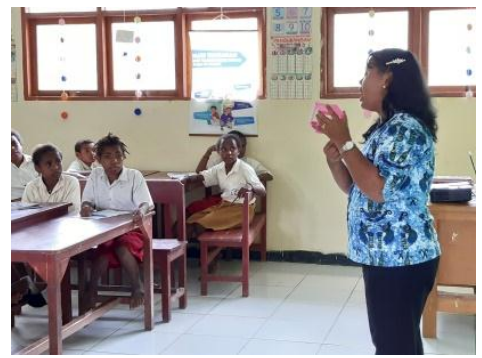

Gambar 4.4 memberikan contoh bangun kubus dan balok

Setelah melakukan kegiatan pendahuluan guru masuk pada kegiatan inti dimana terdapat enam tahap. Pada tahap pertama yaitu pemberian rangsangan, guru yang telah mengelompokkan siswa dalam empat kelompok yaitu 2 kelompok kubus, dan 2 kelompok balok. Guru melakukan rangsangan dengan menggunakan aplikasi geogebra. Guru memilih geogebra karena di sekolah tersebut guru belum pernah menggunakannya, dengan harapan dapat menarik siswa dengan tampilan geogebra yang menarik. Kubus dan balok yang ditampilkan dapat diputar/digerakkan.
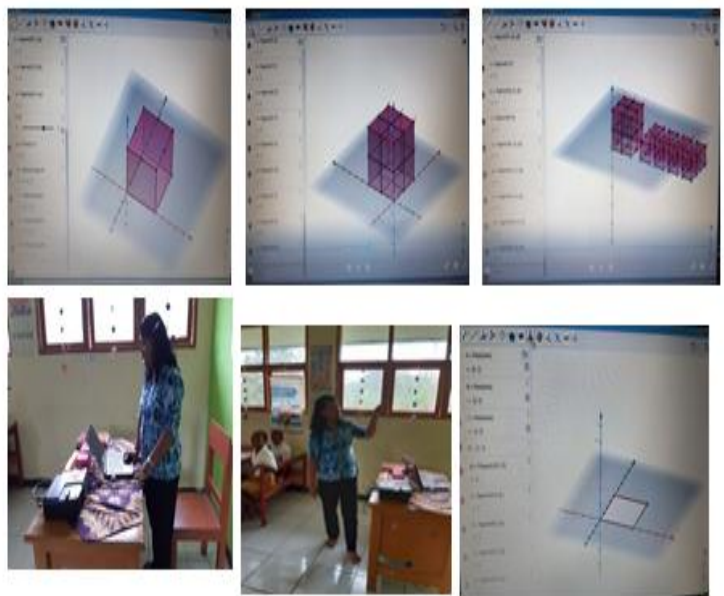

Gambar 4.5 Guru mengajar/memberikan rangsangan dengan menggunakan geogebra

Guru menampilkan kubus besar pertama yang didalamnya terdapat kubus satuan. Selanjutnya guru menampilkan lagi kubus besar yang lain dengan ukuran berbeda yang didalamnya terdapat kubus satuan juga dan seterusnya. Selanjutnya guru menampilkan balok besar yang didalamnya terdapat kubus satuan yang sama seperti di dalam kubus besar sebelumnya. Selanjutnya guru menampilkan lagi balok besar dengan ukuran berbeda dimana didalamnya terdapat kubus satuan dan seterusnya. Siswa sangat antusias pada tahap ini, terlihat dari siswa selalu menjawab pertanyaan yang diberikan guru.

Pada tahap kedua yaitu pernyataan atau mengidentifikasi masalah. Pada tahap ini guru menampilkan kembali kubus dan balok yang telah ditampilkan, setiap kelompok memiliki tugas masing-masing sesuai nama kelompoknya. Siswa dalam kelompok kubus menghitung kubus satuan pada setiap rusuk 
kubus besar. Siswa dalam kelompok balok menghitung kubus satuan pada panjang, lebar, dan tinggi dalam balok besar. Guru mengarahkan masing-masing kelompok mendiskusikan tentang bagaimana menemukan rumus volum sesuai dengan nama kelompok mereka setelah melihat tampilan geogebra. Setelah guru memberikan waktu kepada siswa untuk membuat pernyataan, selanjutnya guru meminta salah satu perwakilan dari tiap kelompok untuk menyampaikan hasil diskusinya. Selanjutnya guru membagikan siswa Lembar Kerja Siswa kepada masingmasing kelompok kemudian memberikan waktu untuk mengerjakan LKPD dan mulai berkeliling untuk membimbing siswa. Langkah akhir pada tahap kedua adalah guru meminta siswa untuk membuat kesimpulan dari LKPD yang akan digunakan pada Lembar Kerja Kelompok (LKK).

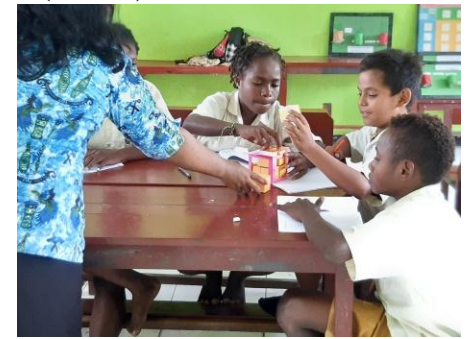

Gambar 4.6 siswa dalam kelompok berusaha menemukan volum kubus

Pada tahap ketiga, yaitu pengumpulan data diawali dengan membagikan alat peraga kubus dan balok besar beserta kubus satuan yang sama dengan kubus atau balok besar dan kubus satuan yang ditampilkan pada geogebra dan LKK kepada masing-masing kelompok dan meminta siswa untuk berdiskusi sambil menyampaikan hasil dari LKPD lalu menuliskannya pada LKK.

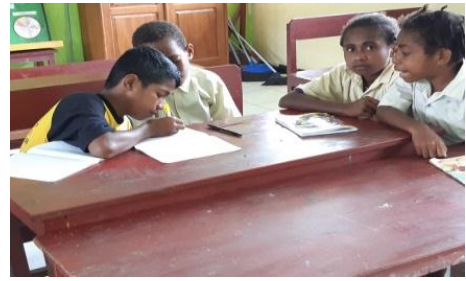

Gambar 4.7 siswa dalam kelompok mengambil kesimpulan volum kubus
Pada tahap keempat yaitu mengolahan data, dimana guru membimbing siswa dalam mengisi LKK dan meminta siswa untuk berdiskusi tentang bagaimana hasil LKPD yang telah dituliskan pada LKK tentang volum bangun sesuai dengan kelompoknya. Selanjutnya guru meminta siswa untuk menyimpulkan hasil diskusinya dari beberapa alat peraga yang berbeda ukurannya, tetapi rumus yang ditemukan semuanya sama.

Pada tahap kelima yaitu pembuktian, siswa diberikan penggaris untuk mengukur panjang kubus satuan, kemudian menghitung volum kubus atau balok sesuai nama kelompoknya. Guru membimbing siswa dalam kegiatan pembuktian dengan melakukan kegiatan tersebut kemudian menghubungkannya dengan hasil pengolahan data apakah hasil penemuannya sama atau tidak. Setelah kegiatan pembuktian selesai guru lalu memberikan kesempatan kepada perwakilan tiap kelompok untuk menyampaikan hasil diskusinya di depan kelas.

dalam kelompok

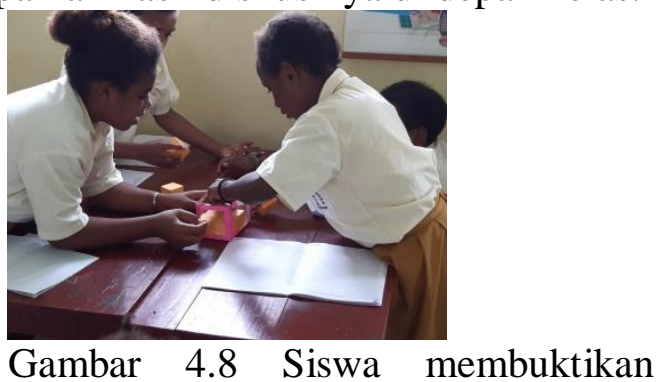

Pada tahap keenam yaitu kesimpulan, guru bersama-sama siswa membuat kesimpulan kemudian guru menuliskan kembali hasil penemuan atau rumus volum kubus dan balok di papan tulis. Selanjutnya guru mempertegas hasil temuan siswa dengan memberikan contoh, namun sebelum itu guru telah membagikan materi ajar terlebih dahulu sehingga memudahkan siswa untuk memahami contoh. Saat menjelaskan contoh di depan siswa juga terlihat antusias menjawab pertanyaan yang guru bagikan dan memperhatikan penjelasan dari guru. 


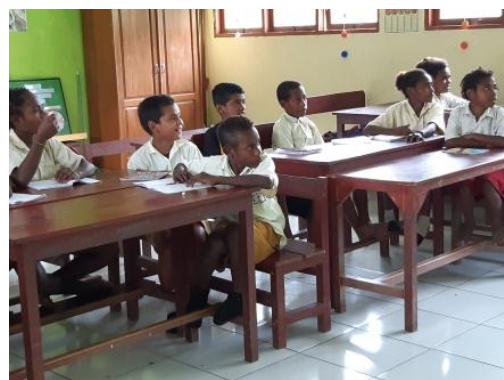

Gambar 4.9 Siswa antusias memperhatikan penjelasan guru

Setelah menjelaskan soal guru membagikan tes individu kepada siswa. Tes dilakukan untuk mengetahui seberapa jauh siswa memahami materi yang diajarkan

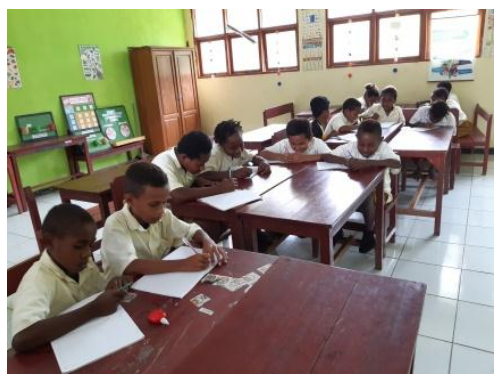

Gambar 4.10 Siswa mengerjakan tes individu

Diakhir kegiatan penutup, guru mengarahkan siswa untuk membuat kesimpulan dari pembelajaran yang telah dilakukan dan menyampaikan materi yang akan dibahas pada pertemuan selanjutnya. Guru juga menanyakan kepada siswa apakah senang mengikuti pembelajaran pada hari ini dan apakah mereka mau belajar lagi dengan model pembelajaran dan media yang sama, semua siswa menjawab senang dan mau. Kemudian guru mengakhiri pertemuan dengan mengucapkan salam.

Hasil Pembelajaran Dengan Menerapkan Model Pembelajaran Discovery learning pada Materi Balok dan kubus.

Hasil dalam penelitian ini diperoleh data sikap yang dimiliki siswa, keterlaksaan model pembelajaran, hasil pengerjaan LKPD, hasil pengerjaan LKK, dan hasil tes individu. Hasil data sikap siswa dan keterlaksanaan model pembelajaran berupa hasil pengamatan dilakukan oleh guru mata pelajaran sebagai observer. Berikut pemaparan dari data hasil penelitian.
Hasil Observasi Sikap Siswa.

Pada penelitian ini, guru kelas $\mathrm{V}$ bertindak sebagai observer. Adapun skor akhir yang dimiliki siswa yang hadir sebagai berikut.

Tabel 4.1 Hasil Rekapitulasi Nilai Sikap Siswa

\begin{tabular}{|c|c|c|c|}
\hline No & Inisial Nama Siswa & Skor Akhir & Kategori \\
\hline 1. & BO & 3,8 & Baik \\
\hline 2. & SM & 3 & Baik \\
\hline 3. & YK & 3 & Baik \\
\hline 4. & MG & 3,6 & Baik \\
\hline 5. & KK & 3 & Baik \\
\hline 6. & DRK & 3,8 & Baik \\
\hline 7. & DL & 4 & Sangat Baik \\
\hline 8. & SK & 3,8 & Baik \\
\hline 9. & YG & 3,6 & Baik \\
\hline 10. & B & 4 & Sangat Baik \\
\hline 11. & MI & 3,8 & Baik \\
\hline 12. & MK & 3 & Baik \\
\hline 13. & JW & 2,8 & Cukup \\
\hline 14. & J & 4 & Sangat Baik \\
\hline 15 & LB & 3 & Baik \\
\hline 16 & WG & 3 & Baik \\
\hline Rata-rata skor akhir & 3,45 & Sangat Baik \\
\hline
\end{tabular}

Dari Tabel 4.1 terlihat bahwa rata-rata skor akhir sikap siswa yang diperoleh dalam penerapan model pembelajaran discovery learning yaitu 3,45 dengan kategori sangat baik. Selama proses pembelajaran siswa dalam kelompoknya dapat saling bekerja sama dan bertanggung jawab dengan baik. Setiap kelompok saling berdiskusi antar anggota kelompoknya jika ada yang kurang dipahami siswa langsung bertanya pada guru. Dari hasil skor akhir yang diperoleh terdapat satu siswa yang memiliki nilai sikap 2,8 dengan kategori cukup. Siswa ini terdapat pada kelompok balok dan terlihat kurang aktif dalam kegiatan pembelajaran.

\section{Hasil Observasi Keterlaksanaan Model Pembelajaran.}

Skor yang diperoleh dari hasil observasi keterlaksanaan model pembelajaran discovery learning pada materi volum kubus dan balok adalah 24. Skor ini menunjukkan bahwa penerapan model pembelajaran termasuk dalam kategori sangat baik. Dengan perolehan skor ini diketahui bahwa semua langkah pada proses pembelajaran yang disusun dalam 
Recana Pelaksanaan Pembelajaran telah dilakukan oleh guru.

\section{Hasil Lembar Kerja Siswa}

Hasil Lembar Kerja Siswa pada tiap kelompoknya dengan menerapkan model pembelajaran discovery learning memiliki hasil yang baik. Hal ini terlihat dari lembar yang mereka telah kerjakan bahwa siswa dapat mengisi perintah yang diminta dan dapat menghitung hasil kerjanya. LKPD yang mereka kerjakan sesuai dengan kelompoknya masingmasing dapat diselesaikan dengan benar dan sesuai langkah pada LKPD yang diberikan.

\section{Hasil Lembar Kerja Kelompok}

Seperti halnya hasil LKPD, hasil Lembar Kerja Kelompok yang dibagikan juga dapat diselesaikan dengan baik dan benar untuk masing-masing kelompok.

\section{Hasil Tes Individu}

Pada tahap keenam yaitu tahap kesimpulan guru membagikan lembar tes individu kepada siswa. Siswa diberikan soal sebanyak dua soal yang mencakup tujuan dari pembelajaran. Siswa diminta untuk mengerjakannya secara mandiri namun, pada saat pengerjaan tes masih saja ada siswa yang saling bertanya sehingga guru lebih sering menegur siswa. Nilai KKM untuk mata pelajaran matematika di SD YPK Diapora yang telah ditentukan adalah 65. Adapun skor akhir yang dimiliki siswa yang hadir sebagai berikut. Tabel 4.2 Hasil Rekapitulasi Nilai Tes Siswa

\begin{tabular}{|c|c|c|}
\hline \begin{tabular}{|l|l|} 
No \\
\end{tabular} & Nama Siswa & Nilai \\
\hline 1. & $\mathrm{BO}$ & 67 \\
\hline 2. & SM & 70 \\
\hline 3. & YK & 50 \\
\hline 4. & MG & 70 \\
\hline 5. & $\mathrm{KK}$ & 67 \\
\hline 6. & DRK & 80 \\
\hline 7. & $\overline{\mathrm{DL}}$ & 100 \\
\hline 8. & SK & 50 \\
\hline 9. & YG & 67 \\
\hline 10. & B & 67 \\
\hline 11. & MI & 67 \\
\hline 12. & MK & 55 \\
\hline 13. & JW & 40 \\
\hline 14. & $\mathrm{~J}$ & 90 \\
\hline 15 & LB & 60 \\
\hline 16 & WG & 60 \\
\hline & Rata-rata & 66,25 \\
\hline
\end{tabular}

Berdasarkan Tabel 4.2 diketahui bahwa nilai siswa yang melebihi KKM di SD YPK Diaspora 10 orang dan 6 orang lainnya berada di bawah KKM dengan rata-rata nilai 66,25 . Hal yang menyebabkan ada nilai siswa yang di bawah KKM adalah siswa kebanyakan saling bertanya antar teman sehingga kurang fokus untuk mengerjakan tes yang diberikan.

\section{PEMBAHASAN HASIL PENELITIAN}

Sebelum masuk dalam kegiatan inti, guru telebih dahulu menanyakan tentang materi prasyarat yaitu perkalian dan pangkat tiga, hal ini maksudkan agar siswa tidak kesulitan dalam menghitung volum kubus dan balok. Materi prasyarat harus dikuasai oleh siswa sebelum masuk pada materi lanjutan hal ini senada dengan hasil penelitian putri dkk.

Guru menerapkan model pembelajaran discovery learning dalam menemukan rumus volum kubus dan balok karena dengan model pembelajaran discovery learning siswa dapat aktif dalam pembelajaran, bekerja sama dan menemuka sendiri konsep, hal ini senada dengan Bruner(Ratumanan, 2004: 50-51) yang memperkenalkan belajar penemuan dimana dalam prosesnya siswa akan berperan aktif dalam menemukan suatu konsep tertentu. Dengan cara ini menurut Bruner akan menghasilkan pengetahuan yang sangat bermakna, selain itu menurut Dahar (Ratumanan, 2004: 52) juga dengan pembelajaran penemuan materi yang diajarkan akan bertahan lama atau lebih mudah diingat.

Guru memilih geogebra karena selama ini siswa belum pernah diajarkan menggunakan media pembelajaran tersebut, selain itu dengan geogebra gambar dapat ditampilkan dari segala arah, dapat diputar sehingga dapat menarik minat siswa belajar. Hal ini senada dengan Syahbana (2016: 2), manfaat program GeoGebra dalam pembelajaran matematika, antara lain: dapat menghasilkan lukisan-lukisan geometri dari yang mudah hingga yang rumit, adanya fasilitas animasi visual dan gerakangerakan manipulasi yang dapat memberikan pengalaman visual dalam memahami konsep geometri. Selain itu, dengan adanya alat peraga 
konkret dapat semakin membantu siswa dalam menemukan dan memahami rumus kubus dan balok. Hal tersebut sejalan dengan teori kognitif dari Bruner, dimana dalam proses internalisasi akan terjadi secara maksimal jika pengetahuan yang dipelajari itu dijikan dalam tiga tahap yaitu enaktif, ikonik, dan simbolik. Siswa akan lebih mudah menerima pengetahuan yang diberikan karena materi yang disajikan dalam bentuk konkretnya sehingga akan lebih mudah.

SIMPULAN

Pembelajaran dengan menggunakan model pembelajaran discovery learning berbantukan geogebra membuat siswa menjadi antusias belajar. Dari hasil observasi siswa dan guru berada pada penilaian sangat baik. Lebih dari separuh siswa hasil belajarnya memenuhi KKM.

\section{Daftar Pustaka}

Putri, dkk. 2014. Pengaruh Penguasaan Materi

Prasyarat Tehadap Hasil Belajar

Matematika Siswa Kelas VIII SMPN 1

Sinjai Timur. Mapan; Jurnal

Matematika dan Pembelajaran. Vol 2,

Nomor 1, Juni 2014

Ratumanan. 2004. Belajar dan Pembelajaran.

Ambon: Unesa Press.

Syahbana, A. 2016. Belajar Menguasai

Geogebra (Program Aplikasi

Pembelajaran Matematika).

Palembang: Noerfikri. 